\title{
Inter-Religious Dialogue: The Perspective of Malaysian Contemporary Muslim Thinkers
}

\author{
AEMY ELYANI MAT ZAIN*, JAFFARY AWANG \& IDRIS ZAKARIA
}

\begin{abstract}
Malaysia is a country that is rich for the diversity of its people. This diversity can be seen from the aspect of faith, ethnicity, language, culture, and so on. In facing a society that is pluralistic in nature, several initiatives have been taken by the government and non-government bodies in ensuring understanding and unity among Malaysians. Among the initiatives taken are interreligious dialogues. In this regard, many among Malaysian thinkers have proposed some approaches and concepts of inter-faith dialogue that should and may be implemented in the context of Malaysia. For that purpose, this paper examined the forms of inter-religious dialogues in Malaysia from the perspective of Malaysian contemporary Muslim thinkers. The methodology utilized in this study is textual analysis, particularly the writings of these thinkers on this issue. This article concludes that there are several forms of inter-religious dialogues that are easily implemented, as well as the difficult ones in the context of Malaysia due to certain obstacles.
\end{abstract}

\section{Keywords: forms of dialogues, inter-religious dialogue, Malaysian Muslims}

Malaysia is a country known for its multi-racial society, religion, language and culture with an estimated population of 23 million people that consists of 200 different ethnic groups (Mansor 2000: 188). The Department of Statistics Malaysia (2011: 5) reported that Malaysian population as of in year 2010 was estimated to be approximately 28.3 million, in which Malaysians make up around 91.8 per cent and the remaining 8.2 per cent are non-citizens. Malaysian citizens consist of Bumiputera ethnic groups (67.4\%), Chinese (24.6\%), Indians (7.3\%), and others $(0.7 \%)$. Malaysian citizens who profess Islam have recorded the highest percentage; $(61.3 \%)$. Meanwhile, Buddhists come in the second place (19.8\%), Christians (9.2\%), Hindus (6.3\%), and the remaining are from other religious groups (Ahmad 2011: 41). The statistics presented above clearly shows that the diversity of race, ethnicity, and religion in Malaysia reflects the uniqueness of this country compared to other countries. Due to multi-ethnicity and multi-racial, the issues of unity and understanding are of very important concern and one of the processes to achieve it is through interfaith dialogues.

The mechanism of interfaith dialogues has long been practiced since the time of the Prophet. Even the Holy Quran also has noted issues regarding inter-religious dialogues that took place during the time of the previous prophets with their people, such as Prophet Abraham (pbuh), Prophet Moses (pbuh), Prophet Noah (pbuh), Prophet Hud (pbuh), Prophet Shuaib (pbuh), and Prophet Saleh (pbuh) (Tantawi 2001; Ahmad Fakhrurrazi \& Wan Nasyrudin 2009). This means the need and role of dialogues in a multi-religious society is so important and is

\footnotetext{
${ }^{1}$ Aemy Elyani Mat Zain*(Corresponding author), Master Student at Dept. of Theology and Philosophy, Faculty of Islamic Studies, Universiti Kebangsaan Malaysia, 43600 BANGI, Selangor, Malaysia, email: elyani12@gmail.com; Jaffary Awang, Ph.D., Associate Professor at Dept. of Theology and Philosophy, Faculty of Islamic Studies, Universiti Kebangsaan Malaysia, 43600 BANGI, Selangor, Malaysia, email: jaffaryawang@gmail.com; Idris Zakaria, Ph.D., Professor at Dept. of Theology and Philosophy, Faculty of Islamic Studies, Universiti Kebangsaan Malaysia, 43600 BANGI, Selangor, Malaysia, email: aris@ukm.edu.my.
} 
enjoined by Islam. Dialogue is also seen as a form of oral missionary endeavour of the apostles who had practiced earlier. Even in the current world context, the role of dialogue as a form of missionary endeavour is not only a need for the religion, but humanity as well. This is clearly reflected by Humaid (2010: 25) who states 'dialogue, thus becomes a religious requirement when its subject is religious, as in inviting people to Islam or explaining the truth to them. But, it is also a human requirement demanded by people's needs and differences'. From another perspective, dialogue can be considered as a strategy to alleviate inter-religious crisis, and also create positive and mutual cooperation (Abdullah 2010: 11).

\section{The Reality of Inter-Religious Dialogues in Malaysia}

In the context of Malaysia, the population is quite different with various ethnic groups and religious affiliations, such as Taoism, Confucianism, Sikhism, Bahaism, and worship of ancestors (Ibrahim 2003: 137), but the main religions in Malaysia are Islam, Hinduism, Christianity, and Buddhism. In short, all religions can be found in Malaysia. Thus, in creating a more peaceful, and harmonious country, as well as complementary and understanding community, in reality, interreligious dialogues have informally taken place among Malaysians, for example, socializing and meetings between different religions in the context of neighbourhood, community, employment, education, and administration, which usually trigger dialogues in an unplanned manner.

Previously, the Muslim community in Malaysia was closed-minded and was not ready for dialogues, especially inter-religious dialogues (Utusan Malaysia 2008). Due to the conservative attitude and uncomfortable feelings among Muslims in accepting the idea of interreligious dialogues compared to non-Muslims, the government has formulated and introduced inter-religious dialogues in a more planned manner for the Islamic organizations. For example, the Department of Islamic Development Malaysia (JAKIM) has taken the role of implementing action plans and has further led other Islamic organizations in conducting inter-religious dialogue activities in Malaysia (Khairulnizam 2008).

In expanding the dialogue between different beliefs, Malaysia does not only focus on the people alone, but the leadership of Malaysia also plays a role, in which the Prime Minister of Malaysia, Najib Tun Razak has involved directly with the 'World Interfaith Harmony Week 2012'. This event involved leaders from various religions, including Islam, and they met, discussed and had a dialogue with each other. In his speech, he stated that the purpose of the event was to inculcate such awareness and understanding among religious believers in Malaysia (New Straits Times 2012). In addition, non-governmental agencies are also sensitive to the needs of interfaith dialogues in Malaysia. Various ways and forms of inter-religious dialogues have been embedded in dialogue activities. Some are conducted in the form of dialogues between religious discourse and discussions, some have the dialogues at informal functions of inter-faith celebration at certain celebration events of certain religious groups, and some have conducted inter-religious dialogues when inter-religious issues arise among them.

Thus, in debating the issues of inter-religious dialogues, there are various views of Malaysian contemporary Muslim thinkers who have given ideas on the concepts and forms, as well as challenges found in these kinds of dialogues. Even peace and understanding intertwined between the people have proven the important role that is played by all parties, be it the government, non-government organisations, and all Malaysians. The same goes to academics, intellectuals, and scholars in Malaysia, who also serve as a complement to the two parties in addressing the issue, and their views on peace and unity among Malaysians. It appears that the mechanism of inter-faith dialogue is among the vehicles that can promote understanding and unity among Malaysia's plural society, whereby the forms of dialogues that occur in Malaysia are varied, depending on its appropriateness to the people. 


\section{Methodology of Writing}

In assessing the forms of inter-religious dialogues advocated by the Malaysian contemporary Muslim thinkers, the method or the approach adopted for this study is the analysis of reading materials, such as documents, papers, books, journals, and articles written by them regarding the inter-religious dialogues in Malaysia. The selection of this group is based on; a) the researches and writings that they often publish related to inter-religious dialogues, especially in Malaysia, b) their academic disciplines or areas of expertise in inter-religious dialogues, and c) they are often invited to forums and seminars related to the discussion of religions in Malaysia.

\section{The Definition of Dialogue}

Dialogue is a term that is often heard and practised by the people of the world. In general, dialogue is a conversation or presentation involving two or more individuals and groups. This statement can be seen through the scientific literature on the meaning of dialogue. For example, Ghazali (1992: 53), Ramli (2008: 37), and Zulkiflee et al. (2011: 275), have mentioned that a dialogue is a process of delivery between two or more individuals or groups.

In Malay language, 'dialog' means conversation; the conversation in the acting, story or whatever forms of speech and exchange of ideas, discussions, and negotiations between two or more parties on an issue in an open manner (Khadijah 2012). Similarly, Saleh (2009: 4) supports that dialogue involves communication between two parties, and elaborates the meaning of inter-religious dialogue in his paper "Institutioning of Muslim-Christian Dialogue: Nostra Aetate and Fethullah Gulen's Vision" states that "Dialogue is understood as meeting and communicating with other faiths, sharing thoughts and exchanging views, and reaching mutual understanding and respect through focusing on common ground". It is clearly illustrated here that to come to an understanding and to change views on the issues discussed are the purposes of having a dialogue. In fact, the interaction process produces a new civilized generation regardless of religion, culture or background (Muhammad Razak 2003: 24). In addition, Azizan sees the concept of dialogue as not just the delivery between two or more parties involved, but the dialogue is a talk with different-minded parties with the primary aim to learn different and new ways of thinking, a way to see the world, and the lives of others (Rahimin Affandi et al. 2011: 93-94).

Additionally, 'dialogue' comes from the root word dia that means what is being said and logos which means brings out the hidden or implied, that the fact/basis of what actually existed at that time that was in fact true and absolute. So, dialogue is the way we manifest the implicit. The idea and the fact of history, culture, and the environment do not have any impact on its own reality and because these things have to be in the form of oral or dialogue (Khadijah 2012: 2). In delivering an implicit idea or something unknown to the other parties involved, of course there would be differences in opinions with each other, but the parties involved would be able to take advantage of those views and ideas (Khadijah 2007: 319).

On the other hand, Ataullah Siddiqui (1997: 56-57) sees the meanings of the dialogues are different depending on the discipline that defines it. According to him, dialogue refers to the consultations, conversations between two or more parties that exchange views with the hope of finally finding an agreement between them. In addition, dialogue can also refer to a person's communication involving speech and hearing of views in front of a group of people with the aim of fostering mutual respect for each other and looking for values that can engender cooperation. Besides, dialogue also refers to communication with adherents of different religions and communities to foster understanding between each other. Dialogue is defined as the involvement of two or more parties that discuss beliefs and their respective religious beliefs, even looking at the conflicts that could possibly erupt between religions and see that cooperation between them is possible. For the final classification of dialogue, Ataullah Siddiqui 
asserts that dialogue is the sharing and exchange of views, and at the same time, its emergence is also an attempt to understand one another and reduce the differences and conflicts between the parties involved.

Whereas, in a much smaller context, the definition of inter-religious dialogue is the closest to its general meaning since the term is similar, but with the aspect of dialogue concerning religions, which involves values, stance, and different beliefs. This can be seen when Kamar Oniah (2010: 129) upon defining 'interfaith dialogue', mentions that it is a form of communication where the parties involved discuss their stance or position of a specific issue. The above definition comes very close to the definition by Fatmir Mehdi (2008: 47) who also perceives a dialog as an interaction between two or more parties with have their own stance in their religious beliefs and perspectives on certain topics that would benefit all the parties involved. In short, this dialogue is not aimed to defeat the other party, but the dialogue is to learn, understand, and increase one's knowledge from the others (Muhammad \& Mohammaed 2007:1). Thus, in formulating the concepts of inter-religious dialogue as a whole, the authors have agreed that an inter-religious dialogue needs to include:

a. The communication process involving a party or representative from various religions.

b. Touches on issues and specific topics from the perspectives of their religions.

c. Beneficial to all involved, especially in the area of producing seeds of inter-religious understanding, and to build good relations between religions.

\section{Forms of Dialogue in Malaysia}

In the context of Malaysia that is rich in racial and religious diversity, the mechanism of interreligious dialogue is something that has its own interests and needs. This can be seen in the debate put forward by academic thinkers in Malaysia who see that the forms of inter-religious dialogues can take place according to the situation and the appropriateness of its participants. Malaysians include the public or 'layman', and intellectuals are the academics, politicians, and religious representatives. Therefore, there are five forms of dialogues that is discussed, namely, a) the dialogue of life or social dialogue, b) dialogue through action, c) intellectual dialogue or discourse dialogue, d) communication of religious experience dialogue, and e) co-'ritual' dialogue.

Dialogue of life is one form of dialogue that occurs in Malaysia (Ahmad Sunawari 2003: 65; Rahimin Affandi et al. 2011: 98). Dialogue of life is also considered as a social dialogue, where some of the features of this dialog include members of a community striving to live outside the confines of their groups which they live openly with and neighbours, along with shared joy and sorrow in the human predicament without being restricted by religious sphere. They also live side by side, in a residential area or village, jointly cooperate and help each other in matters that do not involve religion. In facing their daily lives, each individual with different religious affiliations is able to live and work together, but at the same time, practices his/her religion and reinforces religious faith without formal discussions, but enough through the medium of religious values featured daily (Khadijah 2004: 34; 2006:24). Practicing this life dialogue seems to be able to contain the conflicts, such as hostility and riots that occurred in Kampung Rawa, Pulau Pinang, and Kampung Medan, where religious issues were used as racial hostility sentiment (Khadijah 2004: 34; 2006: 24).

Another advantage of practicing life dialogue is to establish cooperation between religions in the same community. For example, the form of togetherness and religious motivation, especially in dealing with social problems in Malaysia involving people in this country without being confined to certain religions (Khadijah 2004: 34; 2006: 24). The second is the dialogue through action, in which its characteristics can be seen when religious believers agree to plan and perform the act of mutual needs and interests. The advantage of fostering 
dialogue through action is it inculcates different religious believers to act in tandem to ensure that things, such as human rights and universal problems, are looked after together. In other words, efforts to practice dialogue in the form of action are aimed at establishing 'a better human community and a better world' (Ahmad Sunawari, 2003: 66). Generally, such dialogue is carried out by Muslims and non-Muslims from the Non-Governmental Organizations (NGOs) (Rahimin et al. 2011: 98).

In addition, the form of dialogues in the context of Malaysia is the discourse dialogue or intellectual dialogue. This dialogue is divided into three different characteristics and approaches, namely, first, dialogue involving bilateral (two religions only) such as MuslimChristian dialogue. Secondly, trilateral dialogue (trialogue) between Abrahamic Faith that is Judeo-Christian-Islamic, and lastly, multilateral dialogue involving various religions in the same dialogue, such as Muslim-Christian-Hindu-Buddhist (Ahmad Sunawari 2003: 67; Rahimin Affandi et al. 2011: 99). However, Rahimin Affandi (2011: 99) asserts that dialogue environment is very limitedly in Malaysia because it occurs only in institutions of the higher education and the Institute of Islamic Understanding Malaysia (IKIM), and its scope is limited. This is because the dialogue requires a form of soft skills that must be learned and cultivated. In fact, those involved in the dialogue also need to have knowledge in the field of religious studies and comparative religion, besides having expertise in the field of religious scriptures studies other than Islam, and to really understand and master the knowledge on religious culture (Rahimin Affandi et al. 2011: 99).

Apart from the dialogues set forth above, there is another form of dialogue proposed by Khadijah (2004:35; 2006: 25), such as communication of religious experience dialogue, whereby its specific characteristics are exclusively among the highest religious leaders in specific faiths who practice religious worship in a place of other religions to feel the difference in atmosphere and the level of self-confidence. According to her (2006: 25), such dialogue can only be conducted by the leaders of religious groups or for those who would want to know the lives of other religious leaders. Moreover, co-'ritual' dialogue, which corresponds to a 'giant' gathering, is attended by all different faiths to perform religious rituals in the form of their confidence in the pursuit of prosperity and peace. For example, a mass rally in New York after the 9/11 incident, which saw prayer, prayers, and rituals of various religions were performed and universally accepted as a form of dialogue.

Douglas Pratt (2008: 33-34), a Western researcher, who also looked at the reality of the forms and models of inter-religious dialogues, agrees that the four major dialogues are: a) life dialogue (the dialogue of life), b) co-ritual dialogue (the dialogue of action), c) communication of religious experience dialogue (the dialogue of experience), and d) intellectual dialogue (the dialogue of discourse). In giving further details, he stated that the three forms of dialogues and the earliest model occur in the form of informal and unplanned, and the conversations were related to religion or otherwise. In contrast, the intellectual dialogue does not focus on religious practice of certain followers, but rather emphasizes on the understanding between each other, which involves critical thinking and the attitude of empathy for the other dialogue participants (Pratt 2008: 34).

Significantly, the impact of this intellectual dialogue can be seen with the compilation of a module called 'An Indigenous Philosophy Module'. The idea of 'a roundtable dialogue' was triggered by an encounter and dialogue between Samuel O. Imbo and Azizan Baharuddin (Imbo 2011: 15). By using the term 'a roundtable dialogue' in his writing, he further adds details that encounters and dialogues occur in the presence of invitations among scientists and academics from a variety of religions and institutions, such as Universiti Malaya (UM), Universiti Kebangsaan Malaysia (UKM), International Islamic University Malaysia (IIUM), International Institute of Advanced Islamic Studies (IAIS), and Interfaith Spiritual Fellowship (INSAF). They share their views on the issues and the results of the dialogue is the module developed (2011: 19). This means, 'a roundtable dialogue', introduced by Samuel O. Imbo, is a form or a model of 
an intellectual dialogue, which has been discussed earlier because the author observes that the characteristics of 'a roundtable dialogue', which is similar to the intellectual dialogue criteria discussed above. Furthermore, in terms of the definition of inter-religious dialogue, as discussed above, it coincides with a detailed debate by Imbo in his writings.

Nevertheless, this is slightly different from Wan Sabri and Arfah who mentioned four forms and models of inter-religious dialogues, which have been classified by foreign researchers as: a) 'collective inquiry', b) 'critical-dialogic education', c) 'conflict resolution and peace building', and d) 'community building and social action'. He further states that in general, interreligious dialogues in Malaysia can occur as the four dialogue models, for example 'collective inquiry dialogue' that is carried out by INSAF, involving their monthly meeting that is open to the members of various religious backgrounds, ethnicities, and cultures. The issues discussed are religious issues, such as the 'Allah' row, and the 'cow head' issue. On the other hand, 'criticaldialogic education' is usually conducted by the higher education institutions, such as USM Health Campus that organizes 'Minggu Penghayatan Islam', in which the main purpose of this programme is to foster understanding between people of different faiths in Malaysia. The issues and themes discussed are religious doctrines and universal values, such as the concept of divinity, which involves a panel of different religions sharing the issue in the context of their religious beliefs (Wan Sabri \& Arfah 2012: 10-12). Then, 'conflict resolution and peace building' is also similar to 'collective inquiry dialogue', which discusses current issues, including religious and civilization issues. This model is usually practiced by the Centre for Dialogue of Civilisations in the form of seminars, such as 'Muslim Chinese Civilization Dialogue' (2005), and closed-door dialogue, such as 'Dialog antara Penganut Agama Mengenai Isu-isu Semasa' (2008). Such dialogues are usually organized with the objective to find solutions to the issues discussed. The final model is 'community building and social action', which focuses on inter-religious relations, the potential for inter-religious cooperation, and the issues that affect all religions (Wan Sabri \& Arfah 2012: 9-11). Thus, one may conclude that the author has discovered 'collective inquiry', 'critical-dialogic education', and 'conflict resolution and peace building' are a branch or a small aspect that falls under intellectual dialogue or discourse dialogue model. This is because the issues and themes of the dialogue in the third model involve a person who is skilled in the issue, require critical thinking in the dialogue, and an early resolution or frame is built as a result of the dialogue.

\section{Analysis}

Based on the debate on the forms and models of dialogues in Malaysia, the author examines the reality of the application of the models or the forms of inter-religious dialogues in the context of Malaysia and it was found to be varied according to the appropriateness of its applications for Malaysians. Dialogue of life is the most abundant and can easily happen in Malaysia. Generally, Malaysians live in similar and nearby communities, and such dialogue can occur in the context of neighbourhood, learning at universities and schools and workplace. Moreover, the issue of dialogue is also extensive and is not fixed because the dialogue takes place in an informal manner, yet all parties benefit from it.

In contrast to discourse or intellectual dialogue, it involves governmental and nongovernmental bodies to meet and discuss certain issues in a formal and structured manner. In fact, certain criteria must also be available for the parties to be involved, such as personnel who are expert or skilled in the issues discussed, and the need to comply with the dialogue ethics, such as respecting the opponents, be a good listener, and refrain from the act of provocation and aggravating the opponents, as well as sincere in the dialogue (Salih 2010: 42-43). This is because in this discourse dialogue, there are certainly differences and similarities argued by the parties involved. So, to ensure the effectiveness of discourse dialogue and to achieve its objectives, the parties involved must engage in ethical dialogue sessions. 
From the aspect of implementing the discourse dialogue in Malaysia, the authors view that other than the involvements of the Centre for Civilizational Dialogue, University Malaya and INSAF, other agencies also should carry out this intellectual dialogue, for example, the IKIM, and the IAIS, in which the 'core' of these institutions is research. Private higher education institutions are also active in organizing inter-religious dialogue programmes, including Taylor University, Kolej Universiti Islam Selangor (KUIS), and Universiti Teknologi Petronas (UTP). In general, the issues and themes of the dialogues held are very similar to the ones held by the public education institutions that relate to the concept of divinity between the four major religions in Malaysia (Hidayah Centre Foundation 2012).

IKIM is one of the agencies that have been active in interfaith dialogues since its inception. This can be seen from the inter-religious programmes, such as seminars and conferences that have been organized within the country and abroad. Among them are: International seminar entitled 'The Role of Islamic Civilization in Fostering Inter-Religious Understanding' (1999), International seminar and dialogue entitled 'Enhancing the Understanding of Islam for the Media' (2000), Islam Hadhari 'Perang dan Hak Asasi Manusia: Pendirian Agama-agama di Malaysia' seminar (2006), 'A Multi-Cultural Understanding of Filial Piety' seminar (2009), and 'Peranan Agama dalam Menangani Masalah Sosial' seminar (2010).

Based on the review made on inter-religious dialogue programmes that IKIM have organised, it is observed that IKIM has been actively promoted dialogues through discourse. This dialogue involves multilateral dialogues, where the representatives are from Islam, Hinduism, Christianity, Buddhism and Sikhism faiths. The panels that present their opinions in the seminar are not from the public, but they are highly skilled scholars and religious representatives who discuss raised issues, for example, Amir Farid Isahak (INSAF), M. Bala Tharumalingam (Malaysian Hindu Sangam), John Gurusamy (Malaysian Interfaith Network), Wong Choon Tat (Young Buddhist Association of Malaysia), and several others. Another criterion that can be seen from the intellectual dialogue held by the IKIM is the use of English language. From the points of issues and themes of the dialogues, they revolve around humanitarian values and the universal nature. The contents presented by the panel of presenters are knowledge oriented as they debate on the context of their historical and religious symbols, and current issues. The outcome of the dialogue could develop a perception and understanding between religions on certain issues, especially in pluralistic Malaysia.

Next, the authors see social dialogue and joint-action dialogue as two forms of dialogues that do not differ much. The difference may be in terms of terminology and the conduct of jointaction dialogue, which is more formal and structured. For example, the Committee to Promote Understanding and Harmony among Religious Followers (JKMPKA) was formally established in 2010 to conduct inter-religious dialogues to advocate inter-religious interaction in Malaysia in a more formal manner. This can be seen from the mission of the committee to have the dialogue and mediation as a mechanism to create understanding and harmony between religious followers towards developing Malaysia into a goodwill-spirited country (JKMPA nd.).

Meanwhile, as for the communication of religious experience dialogue, and the co-'ritual' dialogue, as discussed earlier, Khadijah gave no further details in terms of its practice in Malaysia. This is because from the aspect of its implementation, it may not be appropriate and is unlikely to happen in Malaysia. Furthermore, writings by other Malaysian contemporary Muslim thinkers on these two forms have not been found. In examining in the context of Malaysia, both forms of dialogues are irrelevant and the primary factor is that it can confuse people, especially Muslims in Malaysia. This could even lead to misconceptions, even more so if the highest religious leader in a particular religion performs religious practice at other places of worship.

In summary, it can be observed that some Malaysian contemporary Muslim thinkers have introduced forms of inter-religious dialogues in Malaysia, namely, a) social dialogue or dialogue of life, b) joint-action dialogue, c) dialogue through discourse, d) communication of 
religious experience dialogue, and e) co-'ritual' dialogue. These five forms of dialogues share two similarities; the involvement of different faiths, and a process of interaction between two or more dialogue groups. The conclusion that can be drawn from this discussion is that the authors view that three of the earliest forms and models of the dialogues, specified by some Malaysian contemporary Muslim thinkers, are appropriate to be practised in the Malaysian context. It appears that the intellectual dialogue or dialogue through discourse has the potential to be expanded further and is relevant to be practised by the government agencies and the NonGovernmental Organizations in Malaysia because the characteristics and criteria possessed by the intellectual dialogue are able to produce understanding among the different faiths in Malaysia and establish good relationship among the plural society of Malaysia, especially when sensitive issues arise that involve religion and should be addressed together through interfaith dialogue mechanism. Meanwhile, the last two forms of dialogues discussed above, even theoretically seem easy to apply, but considering the present context of Malaysia, it would be just irrelevant and difficult in practice. This is due to the obstacles, such as the widespread confusion among Malaysian Muslims. In fact, in Malaysia, the majority of the population are Muslims who are steadfast to Islam and do not compromise with other religions, especially in terms of faith. Islam is a way of life based on what is stated in the Quran, surah al-Kafirun: 1-6. However, from the point of conducting inter-religious dialogues, it is allowed and advocated in Islam.

\section{Acknowledgements}

This study was funded by Research University Grant, the National University of Malaysia and Ministry of Education Malaysian [Grant Code: GPP-2011-010].

\section{References}

Abdullah Abul Mohsin al-Turki. 2010. Dialogue between followers of religions from Makkah to New York. In. Interfaith dialogue cross-cultural views, pp. 10-21. Riyadh: Ghainaa Publication.

Ahmad Fakhrurrazi Mohammed Zabidi \& Wan Nasyrudin Wan Abdullah. 2009. Dialog dengan non-Muslim: Iktibar dari kisah para Nabi dalam al-Quran. Prosiding Seminar Antarabangsa Ketamadunan Islam ISCIS II (Dialog Antara Agama: Pemangkin Keharmonian Agama), p. 43-48. Perak: Pusat Perkembangan Kolej Islam Darul Ridzuan.

Ahmad F. Yousif. 2011. Religious freedom minorities and Islam: An Inquiry into the Malaysian experience. Kuala Lumpur: IIUM.

Ahmad Sunawari Long. 2003. Dialog antara agama-agama pra syarat persefahaman antara agama-agama. In. Jaffary Awang, Mohd Nasir Omar \& Muda @ Ismail Ab. Rahman (eds.). Agama dan Perpaduan Kaum di Malaysia, p. 62-75. Bangi: Universiti Kebangsaan Malaysia.

Ataullah Siddiqui. 1997. Christian-Muslim dialogue in the Twentieth Century. London: Macmillan Press.

Fatmir Mehdi Shehu. 2008. Nostra Aetate and the Islamic perspective of inter-religious dialogue. Kuala Lumpur: IIUM Press.

Ghazali Basri. 1992. Christian Mission and Islamic Da'wah in Malaysia. Kuala Lumpur: Nurin Enterprise.

Hidayah Centre. 2012. Interfaith dialogue: The concept of God. Hidayah Centre Foundation. http://hidayahcentre.wordpress.com/2012/10/15/sekitar-interfaith-dialog-theconcept-of-god-taylors-university-subang-jaya. [7 Oct 2012].

Humaid, Salih Abdullah. 2010. The Islamic views of dialogue with the Other. Interfaith dialogue cross-cultural views, pp. 24-47. Riyadh: Ghainaa Publication. 
Imbo, S.O. 2011. Towards developing an Indigenous Philosophy Module: A roundtable dialogue. Kuala Lumpur: Pusat Dialog Peradaban Universiti Malaya.

JKMPA. nd. Visi dan Misi. http://www.jpnin.gov.my/visi_jkmpka [20 June 2014].

Kamar Oniah Kamaruzaman. 2010. Religion and pluralistic co-existence (a collection of seminar papers). Kuala Lumpur: IIUM Press.

Khadijah Mohd Hambali @ Khambali \& Khairul Nizam Mat Karim. 2004. Interaksi dan dialog agama (dialog peradaban): Satu paparan. Working Paper. Perbincangan Meja Bulat 'Dialog Peradaban': Perspektif Tamadun Islam. Civilisational Dialogue Center, Universiti Malaya. November, 23.

Khadijah Mohd Hambali@ Khambali \& Khairul Nizam Mat Karim. 2006. Dialog antara agama (dialog peradaban): Realiti, aplikasi dan cabaran. Working paper. Seminar Islam dan Hubungan antara Agama di Malaysia Peringkat Kebangsaan. Organised by Jabatan Akidah dan Pemikiran Islam, Akademi Pengajian Islam, Universiti Malaya. January, 1819.

Khadijah Mohd Hambali@ Khambali. 2007. Umat Islam, dialog antara agama dan toleransi beragama: Rujukan kepada artikel II Perlembagaan Persekutuan Malaysia. Persidangan Undang-Undang Tuanku Ja'afar, p. 317-338. Selangor: Fakulti Undang-Undang, Universiti Kebangsaan Malaysia.

Khadijah Mohd Hambali@Khambali. 2012. Dialog antara agama di Malaysia: Isu, pendekatan dan etika. Persidangan Dialog antara Agama, p. 1-28.

Khairulnizam Mat Karim. 2008. Hubungan antara agama. Utusan Online. http://www.utusan.com.my/utusan/info.asp?y=2008\&dt=0208\&pub=utusan_malaysia \&sec=Rencana\&pg=re_01.htm. [8 Jan 2013].

Mansor Mohd Noor. 2000. Social conflicts in Indonesia and Malaysia: Could the cause be religious? Kajian Malaysia. XVIII (1 \& 2): 188-206.

Muhammad Razak Idris. 2003. Dialogue of civilizations: Islam and the West. MA Thesis. Department of Philosophy, Republic of Sudan Juba University.

Muhammad Shafiq \& Mohammaed Abu Nimer. 2007. Interfaith dialogue: A guide for Muslims. USA: International Institute of Islamic Thought.

New Straits Times. 2012. PM meets religious leaders (15/02/2012). http://www.nst.com.my/top-news/pm-meets-religious-leaders-1.46912. [8 Jan 2012].

Pratt, D. 2008. Faith to faith: Issues in interreligious engagement. Oxford: Ripon College Cuddesdon.

Rahimin Affandi Abd Rahim, Mohd Anuar Ramli, Paizah Ismail \& Nor Hayati Mohd Dahlal. 2011. Dialog antara agama: Realiti dan prospek di Malaysia. Kajian Malaysia 29(2): 91-110.

Ramli Awang. 2008. Dialog antara agama dari perspektif al-Quran. Johor: UTM.

Saleh Yucel. 2009. Institutioning of Muslim-Christian dialogue: Nostra Aetate and Fethullah Gulen's vision. http://www.fethullahgulen.org/conference-papers/gulen-conference-inmelbourne. html. [20 Feb 2012].

Tantawi, Muhammad Sayid. 2001. Etika dialog dalam Islam. Trans. by Ahmad Zamroni Kamali \& Abdul Hafids Zaid. Indonesia: Mustaqim.

Wan Sabri Wan Yusof \& Arfah Ab. Majid. 2012. Inter-religious dialogue models in Malaysia. Global Journal al-Thaqafah 2(1): 7-13.

Zulkiflee Haron, Ramli Awang, Mohd Nasir Ripin, Siti Norlina Muhamad, Farahwahida Mohd Yusof. 2011. Tamadun Islam dan Tamadun Asia. Johor: UTM Press. 